\section{АРХИВ ЗАРУБЕЖЬЯ}

Юлия Горячева

\section{Мемуары Сергея Голлербаха (США) - яркий портрет современников выдающегося художника второй волны эмиграции}

Живописеи, эссеист и мемуарист Сергей Голлербах является автором уникальных ме муаров о мастерах культуры второй волны эмиграции, преимущественно поколении ди-пи. В поле внимания рассматриваемых мемуаров - мир Русского Зарубежья послевоенного Нью-Йорка и его ярких представителей: Михаила Вербова, Ивана Елагина, Владимира Одинокова, Леонида Ржевского и других известных литераторов и художников. Мемуары Голлербаха приоткрывают тайну его становления как художника знакомят читателя с его пониманием основных принципов искусства.

Ключевые слова: русская эмиграция, русское зарубежье, Сергей Голлербах, мемуаристика, вторая волна, «ди-пийцы», эмиграции, художник, литератор, поэт, США, соотечественники за рубежом

$$
\begin{aligned}
& \text { Судъба - это случай в квадрате, } \\
& \text { амы ииркачи на канате, } \\
& \text { идем по нему осторожно } \\
& \text { между Возможно и Невозможно. } \\
& \text { Сергей Голлербах }[6, \boldsymbol{c} \text {. 7] }
\end{aligned}
$$

Сергея Львовича Голлербаха, американского художника русского происхождения, нет нужды представлять знатокам и ценителям русской Америки. Исследователям живописи он известен прежде всего своими нью-йоркскими зарисовками. В США его репутация как одного из наиболее ярких русских художников

\footnotetext{
${ }^{1}$ В сокращении данный текст был опубликован в издании «Литературная Америка»: Горячева Ю. Свет отраженный // Литературная Америка. 2020. URL: https://literaryamerica.ru/almanakh/pub/svet-otrazhennyy. html (дата обращения: 20.06.2020)
}

Горячева Юлия Юрьевна, член Союза журналистов Москвы, член редколлегий альманаха «Литературная Америка» (США) и альманаха «Связь времен» (США), автор книг и статей по истори русского зарубежья (Москва), tygor67@gmail.com современной Америки получила подкрепление высокими регалиями - он действительный член Национальной академии художеств (Нью-Иорк), почетный президент Американского общества акварелистов, член Общества художников Одюбон... В свою очередь, любители русской словесности ценят его отточенные эссе, публикующиеся с 1976 г. в «Новом журнале», старейшем и наиболее авторитетном литературно-публицистическом издании русского зарубежья, и высоко отзываются об автобиографических книгах Голлербаха [2-8].

Емко и точно о Голлербахе отозва лась Валентина Синкевич, известный поэт и его давний соратник (в том числе и по деятельности в корпорации «Новый журнал»), в әссе, опубликованном в связи с празднованием 90-летия художника, отмечавшемся как в США, так и в России. «..ЖЖивописеи, график, эссеист, искусствовед, мемуарист, а с недавнего времени и поэт, Сергей Львович Голлербах является неотбемлемой ча стью русской культуры и, я бы сказала, ито его можно считать символом творческого выживания в далеко не легких условиях на шего недавнего исторического прошлого», поделилась Синкевич в калифорнийском русскоязычном альманахе «Связь времен» [12, с. 29]. По мнению этого авторитетного исследователя культуры русского зарубежья, из всех рус- 
ских художников, с которыми ее свела судьба, Голлербах является «наиболее жизнеутверждающей и иельной твориеской натурой, не пребываюшей в постоянном конФликте со своим внутренним и внешним миром» [12, с. 32].

...Сергей Львович Голлербах родился 1 ноября 1923 года в Царском Селе, где прочно обустроилась семья деда Федора Георгиевича Голлербаха - знаменитого кондитера с немецкими корнями. Другой дед художника - по материнской линии - Алексей Алексеевич Агапов был российским кадровым военным, директором Воронежского кадетского корпуса, затем - генералом для особых поручений при великом князе Константине Константиновиче, шефе всех кадетских корпусов России.

В 1935 г. отец, инженер Лев Федорович Голлербах, был арестован, а мама - урожденная Людмила Алексеевна Агапова - выслана с сыном в Воронеж. Несмотря на лишения, об этом периоде у Сергея Голлербаха остались светлые воспоминания: в Воронеже он начал заниматься в изостудии Дома пионеров. В 1937 г. после возвращения в Ленинград (в связи с освобождением отца) Сергей продолжил занятия в художественной школе при Академии художеств, но война помешала его обучению: он был угнан вместе с матерью в феврале 1942 г. в Германию из оккупированного немецкими войсками Царского Села. Весной 1945-го узники лагеря, где находился Голлербах, были освобождены американскими войсками. Сергей оказался в лагере для перемещенных лиц, управлявшемся американским «Красным Крестом». Осенью 1949 г. с помощью Толстовского фонда на американском судне «Генерал Баллу» Голлербах перебрался в США, в Бостон. Потом переехал в Нью-Йорк, с которым связал свою дальнейшую судьбу. Вот как рассказывает художник о первых шагах творческого ста- новления: «В Америку попал в самый расивет абстрактного экспрессионизма, и в одной группе художников на меня явно смотрели, как на мальчика, все еще играющего в солдатики (фигурные композичии), в то время как они, «взрослье», занимаются вешами сервезными - соотношениями иветовых плоскостей, напряжениями линий и так далее. Но я уже знал, что правда в искусстве подобна одной забавной истории в старом английском фильме. Космический слуга-негр рассказывает: "Было нас у матери двенадиать человек, а отиъ-то у всех разные. Но мать всегда говорила нам: пусть это вас не смущает, дети, ибо у всех нас только один отеи - Отеи Небесный» [8, с. 205].

С деталями творческого пути художника можно ознакомиться благодаря его мемуарам (был период работы в мастерской шелкографии «Хильда Ньюмен Студио», занятия офортом в графической мастерской Академии, двадцатилетний период преподавания живописи в художественной школе Национальной академии дизайна, (основанной в 1825 г. Сэмюэлем Морзе, художникомпортретистом, впоследствии изобретшим «азбуку Морзе»)...

Голлербах неустанно подчеркивает: уникальной творческой манерой, о которой емко сказал в дружеской эпиграмме Иван Елагин, поэт, высоко чтимый второй волной эмиграции («Угловатъе уроды // Голлерба ховской породы // Наклонялотся со стен // В них-иувствительность антенн» [8, с. 868]), обязан прежде всего ньюйоркским наблюдениям. Вот как он сам об этом размышляет: «И только здесь в Америке, на вонюмих скамейках Бауэри и Бродвея, рисуя спяиих пьяных и бродяг, я «нашел себя», то есть махнул рукой и перестал стыдиться гротеска, иллюстративности...» [8, с. 205]. За свою профессиональную жизнь Голлербах «сделал тысячи набросков с натуры, рисуя людей в парках, в кафе, сидя на уличных скамей- 
ках. Чаще всего это был так называемый «простой народ», бывали и старики, и старухи, видавшие в своей жизни лучшие дни» [7, с. 181].

С Нью-Йорком связана и литературная карьера Голлербаха: его первые материалы были опубликованы в 1960 г. именно «Новым русским словом», эмигрантской газетой, существовавшей столетие. Благодарность Андрею Седых, легендарному главному редактору «Нового русского слова», пронзительно передана в ньюйоркских мемуарах: в ярком эссе, посвященном этому «последнему из могикан», служившему в свое время секретарем у Ивана Бунина, мастерски отображены грани многомерной личности. Впоследствии заметки живописца, среди которых обзоры художественных выставок в США, очерки о русских художниках эмиграции, а также воспоминания о своей жизни, стали печататься в газете «Русская мысль», в журнале «Континент» (Париж), в «Новом журнале» (Нью-Йорк). Сергей Львович стал преданным автором издательства «Альбатрос», созданным его почитателем, известным французским славистом и коллекционером творчества русских эмигрантов Рене Герра. Голлербах известен оформлением книжных обложек. Из мемуаров художника становится известно, что он оформлял книги вашингтонского издательства «Международное литературное содружество», возглавляемого известным литератором Борисом Филипповым (Борис Филистинский), с которым познакомился еще в 1946 г. в Мюнхене. В частности, для этого вашингтонского издательства в конце 1960-х Голлербах оформил собрания сочинений Анны Ахматовой, Максимилиана Волошина, Евгения Замятина, Николая Клюева, Осипа Мандельштама... Он оформлял и обложки изданий своих друзей-литераторов: Леонида Ржевского, Вадима Крейда, Лидии Алексеевой, Татьяны
Фесенко... Довелось художнику выполнить и суперобложку книги известной американской писательницы Сюзанны Масси «Страна Жар-птица» в издательстве «Саймон энд Шустер».

О кредо и творческом стиле Голлербаха-мемуариста лучше всего сказано им самим в предисловии программного сборника «Свет прямой и отраженный»: «В жизни, видя большинство вещей и событий в прямом свете, мы улавливаем и отраженный свет. Как его определить? Это наблюдения, воспоминания и сравнения, случайнъе находки и игра фантазии. И, конечно, голос совести, сознание собственной недостаточности и желание что-то понять и исправить. Может быть, вся жизнь человеческая есть постепенное изменение освещения, переходы прямого света в свет отраженный. Так, во всяком случае, кажется мне и побуждает меня записывать виденное, пережитое и воображаемое, не следуя какому-либо определенному плану, а лишь разделяя мои впечатления и мысли на отдельные группы» [8, с. 7].

В вышеупомянутый сборник вошли статьи и эссе, $\mathrm{co}^{-}$ держащие яркие психологические и философские прозрения Голлербаха. И все же эта книга, как и последующие, - прежде всего книга художника. Автор в своих зарисовках постоянно говорит о себе как о человеке «зрительном», идущем от внешних впечатлений, художнике. Символично, что «Сильные ракурсы», первая часть этого внушительного сборника, включают статьи о художественных выставках и рассказы о собратьях по кисти. Стилистика книги также обусловлена тем, что их автор - художник. Именно зрительные впечатления дают Сергею Голлербаху творческие импульсы, порождающие и его художественные картины, и глубокие нетривиальные размышления, в свою очередь, становящиеся настоящей литературой. Недаром некоторые авторитетные исследователи русского зарубежья, 
в частности, Вадим Крейд и Виктор Леонидов сравнивали мемуарную прозу Голлербаха с знаменитыми «Опавшими листьями» Василия Розанова.

Интересно признание писателя: стиль художника формировали первые детские впечатления. Поскольку квартира Голлербахов отапливалась дровами, он обожал еще дошкольником вместе с матерью бывать в дровяном складе, внимательно рассматривая поленья, что, как ни парадоксально, повлияло на его стиль рисовальщика. «В зависимости от характера первых детских впечатлений художники становятся на всю дальнейшую жизнь «полянами», «древлянами», «гориами», «водяными» и так далее. Дело не в сюжете произведений, а именно в изначальном ощущении материи, фактуры. Мне лично сучки, волокна, изломъ ветвей навсегда привили вкус к крепкой линии, поворотам, завиткам. Не жив около воды, я не чувствую отражений, атмосферической игры света, дымок и далей. Это не мой элемент. Зато складки одежды привлекают логикой падения ткани, своеволием фактуры, ложащейся именно так, а не подругому» [8, с. 648], - образно приоткрывает составляющие своего стиля художник.

Если «Свет прямой и отраженный» знакомит нас с творческим стилем Голлербаха-философа, то «НьюЙоркский блокнот» демонстрирует нам Голлербаха-репортера. Страницы «Блокнота» повествуют, как открывали «город Большого Яблока» такие же, как он, русские эмигранты первых послевоенных лет; какие профессии преимущественно осваивали (доходило до фантасмагорического: «какая-то русская семья решила посмотреть индейские резервачии, то есть поселения еще существующих североамериканских племен. <... Гариевало несколько всадников в головных уборах с перыями, под звуки барабана исполнялись индейские пляски. Когда иеремония закончилась, двое индейцев слезли с коней и один сказал другому по-русски: «Гриша, подводи коня») [7, с. 42]; как и где практиковали русские врачи, о художественных салонах, содержавшихся русскими. В их числе салон матери Сергея, дочери царского генерала, дававшей в послевоенном Нью-Йорке уроки разговорного русского языка и занимавшейся переводами. На домашних творческих встречах, устраиваемых ею, бывали поэтесса Валентина Синкевич и художник Владимир Шаталов, Иван Елагин, поэт Ольга Анстей, художники Бобрицкий, Николенко и Гороховец, известный литератор и преподаватель НьюЙоркского университета Леонид Ржевский с женой-поэтессой Агнией; поэт Глеб Глинка, предложивший однажды на традиционное общее обсуждение тему жалости, столь типичной для русского характера; скульпторы Андрей Дараган и Олег Соханевич, переплывший в 1968 г. Черное море и попросивший политического убежища в Турции.

Чрезвычайно интересны воспоминания Сергея Львовича и о религиозно-философских беседах, проводившихся в доме Александра Шмемана, известного священнослужителя Православной церкви в Америке.

С особой теплотой Голлербах пишет о знаменитом салоне Ржевских: «У них любили бывать, потому ито «легко дышалось», было тепло и, конечно, всегда интересно» [7, с. 89].

Следует отметить и главы «Нью-Йоркского блокнота», посвященные «русским оазисам» в Нью-Йорке. К примеру, «Русский Бродвей» («Русским Бродвеем можно было бы считать район, начинающийся на 60-х и заканчиваюшихся на 180-х улииах» [7, с. 18]), «Вашингтонские высоты и их обитатели», «Общество русских художников», «Музей Рериха и Зал имени Рахманинова». Для исследователей истории русской православной церкви особенно интересно именно это эссе. Сергей Львович обстоятельно и тепло пишет о священнике 
Александре Киселеве, позже ставшим настоятелем Свято-Серафимовской церкви, при которой в том же здании был открыт Зал имени Рахманинова, где проходили знаменитые литературные вечера, поэтические чтения, театральные постановки, лекции. Отец Александр известен своей давней дружбой с Патриархом Всея Руси Алексием Вторым, в отроческие годы помогавшим ему в качестве алтарника, а впоследствии поспособствовавшим его переезду в 1991 г. в Россию.

Сергей Львович Голлербах - мастер не только самобытных городских зарисовок, но и уникальных мемориальных материалов - некрологов. Стремление редакций «Нового русского слова» и «Нового журнала», знаковых эмигрантских изданий, доверять создание столь деликатных «веховых» материалов именно Голлербаху, обусловлены благородством автора, безупречностью его художественного вкуса и доскональным знанием перипетий судеб своих товарищей.

С огромным уважением Голлербах пишет и о собратьях-художниках. Среди моих любимых эссе этой серии - материал, посвященный Владимиру Одинокову, художнику, заведовавшему в послевоенные годы всеми сценическими мастерскими «Метрополитен-оперы». В нем Голлербах приоткрывает тайну Шагала: его известные полотна, украшающие по сей день стеклянный фасад «Метрополитен-оперы» в Манхэттене, на самом деле написаны Одиноковым.

...Об особом даре Сергея Голлербаха легко и доверительно рассказывать о коллегах и сподвижниках, вводя их имена в культурный контекст мировой художественной культуры, подмечая мельчайшие, столь важные для потомков и соотечественников детали быта и бытия даровитых современников и соотечественников, очень верно отозвался известный поэт второй волны эмиграции Олег Ильинский в рецензии на книгу Голлербаха «Мой дом. Воспоминания и эссе»: «Его эссе, в которых автобиографический материал переосмыслен опьтом жизни, неотбемлемой от активной и плодотворной работь в искусстве, возникают попутно, почти как заметки на полях $[11$, с. 362].

...Подлинную тайну литературного труда Сергея Голлербаха точно подметил известный писатель и издатель русского зарубежья Борис Филиппов (Борис Филистинский): «Художник линии и ивета Голлербах смотрит на мир, выбирая самое для него ярко характерное. Иего живописное и графическое творчество - трагедофарс по преимуществу. Но, обращалсь к слову, он вдумчив и жалостлив. Не сентиментален. Нет, а так, как в народе: жалеть - означает любить. Сочувствовать. И думать и о смысле творчества, и о задачах его. Сомневаться. Надеяться» [8, с. 261].

Мемуарные заметки Сергея Голлербаха открывают его как человека, высоко ценящего роскошь человеческого общения (Голлербах невероятно контактен и терпим) и умеющего щедро отдавать свой человеческий капитал единомышленникам. Пронзительно щемяще пишет Сергей Голлербах о поездке в Питтсбург с намерением показать поэту Ивану Елагину, давнему товарищу, умиравшему от смертельной болезни, обложку и шрифты его предсмертной книги «Тяжелые звезды», которая стала также последней редакторской работой их общего близкого друга Леонида Ржевского.

Об особенностях «прозы поэта» написано много. В то же время не менее интересный феномен, специфика «прозы художника», изучена мало. К ярким представителям этого цеха относятся, к примеру, Анненков, Бенуа, Грабарь, Кандинский, Петров-Водкин, Репин, Шагал... Можно с уверенностью сказать, что мемуаристика Голлербаха - редкая жемчужина в этом ряду. 
Об этом точно говорит российский поэт и искусствовед Юрий Кублановский: «отжатая, лапидарная и ярко визуальная очерковая проза Голлербаха может быть расиенена и как жанр «стихотворений в прозе»: стихотворений, где трезвая житейская философия работает не на занижение, а на организачию поэтизачии мира» [8, с. 867].

Действительно, биографические элементы мемуаристики Голлербаха воспринимаются как основа и как повод поговорить с читателем об эпохе, искусстве, идеалах, мастерах. Царскосельское детство, недолгий период жизни в Воронеже, учеба в 1946-1949 гг. в Художественной академии в Мюнхене; беспристрастные зарисовки из жизни «перемещенных лиц» в Америке, рассказы о творческих реалиях художников-собратьев, - о чем бы ни писал Сергей Голлербах, постоянно ощущается и взгляд, и рука художника. При этом автор поднимается над обыденной реальностью, выводя читателя на образные философские обобщения. Наблюдения литератора имеют отношение непосредственно к сути искусства. «Мне всегда казалось, что так называемая «тайна искусства» лучше всего оббяснена в следуюшем, делится он, - Адам и Ева были изгнаны из Рая и стали смертнъ. Но они сохранили в себе памлть и тоску по утерянному Раю. Эта тоска заставляет нас, потомков, фиксировать образы окружающего мира, стараясь сохранить их «для вечности», итобы таким образом самим к ней приобщиться» $[8$, c. 10$]$.

Возможно, философичный стиль Голлербаха обусловлен влиянием генов: его дядя, Эрик Федорович Голлербах - известный искусствовед и критик эпохи Серебряного века, с ним Сергей общался в детстве.

Многолетняя педагогическая деятельность (Сергей Голлербах долгие годы преподавал живопись в художественной школе Национальной академии дизайна в Нью-Йорке, о нюансах этой работы он рассказывает в главе «Нью-Йоркского блокнота» «Мои студенты»), безусловно, наложила отпечаток на стиль мемуариста. В автобиографических книгах он много рассуждает о духовных ценностях, о соотношении формы и содержания, целей и задач изобразительного искусства и его воспитательной роли в обществе.

Несомненно, и то, что «Нью-Йоркский блокнот»единственная в своем роде книга эмигранта - яркого представителя поколения Displaced Persons (Ди-Пи, «перемещенных лиц»), второй волны эмиграции в США и о послевоенном Нью-Йорке, уникальном по своему культурному коду, является своего рода проводником в мир искусства русского зарубежья. Фактом создания и издания этого труда, состоящего из удивительных историй о знаменитых собратьях-художниках и скульпторах первой волны: Илье Болотовском, Глебе Дерюжинском, Иване Олинском, Николае Циковском, Ростиславе Сазонове и собратьях по кисти и инструментам скульптора, представлявших столь знакомую ему вторую волну, - Юрии Бобрицком, Андрее Дарагане, Вячеславе Иляхинском, Владимире Лебедеве, а также о собратьях-литераторах-«ди-пийцах»- Ольге Анстей, Глебе Глинке, Иване Елагине, Клавдии Завалишине, Сергее Королькове, Валентине Синкевич, Леониде и Агнии Ржевских, Борисе Филиппове (Филистинском) Голлербах сохранил для истории имена многих современников, достойно представлявших цвет культуры русской Америки.

Совершим небольшой экскурс в историю поколения ди-пи, ярким представителем которого является Голлербах. Согласно документации Управления уполномоченного Совета Народных Комиссаров (Совета Министров) СССР по делам репатриации, «установлено, ито 
к конщу войны за пределами страны оказалось около пяти миллионов советских граждан» [9, с. 103]. Из них около двух миллионов - в преимущественно европейской зоне действия Красной Армии. Свыше трех миллионов находились в зоне действия союзников на территории Германии, Франции, Италии и других. Большинство из них составляли «восточные рабочие» - «остарбайтеры» - люди, подобно Голлербаху и его маме, перемещенные принудительно на работы в Германию и оккупированные ею соседние страны; около 1,7 млн человек - военнопленные. Общее же число беженцев и перемещенных лиц из разных стран, оказавшихся в условиях неволи и концлагерях, составляло многие миллионы. Согласно статистике, бывших «ди-пийцев» в Германии и Англии обосновались на постоянное жительство 13 тысяч. К 1951 г. 77,4 тыс. беженцев оказались в США; 25,2 тыс. - в Австралии; 23,2 тыс. в Канаде; 4,4 тыс. - в Аргентине; 6, 4 тыс. - в Бразилии; 8,3 тыс. - в других странах.

Как утверждают исследователи предпосылок второй волны эмиграции, не будь сталинского приказа, «оббявлявшего каждого оказавшегося в плену советского солдата предателем, <...>, не создай государство репрессивного механизма обрашения с вернувшимися гражданами, сведения, о чем доходили до лагерей ди-пи, не было бъ и второй эмиграиии» [1, с. 205].

Әтой горькой теме Сергей Львович уделяет внимание в главе «Тяжелые времена и их последствия» вышеупомянутой книги, рассказывая, в частности, о подвижнической деятельности Александры Толстой, много сделавшей для «перемещенных лиц»: «граждане, не по своей воле оказавшиеся в оккупированнъх немиами областях или насильственно вывезенные на работу в Германию, знали, что Сталин этого им не простит, и возврашаться боялисъ». <... К Кое-кто из бъвиих советских граждан доставал себе фальшивые документы, в которых говорилось, ито данное личо родилось в Югославии или Польше. Такой документ имелся у писателя Родиона Березова (Акульшина). Эмигрировав в Америку, он в этом покаялся, далее стали каяться и другие, болевшие так называемой «березовской болезнъю». Эмиграиионные власти не без участия графини Александры Толстой, зашитничъ русских беженцев, простили им этот, възванный страхом, обман, и «березовская болезнъ» перестала суијествовать» [7, с. 32].

Там же Голлербах отмечает и особую роль Толстой и ее помощницы Татьяны Шауфус в открытии в Мюнхене специального бюро, призванного содействовать беженцам «ди-пийских» лагерей и переезде желающих в США по линии Толстовского фонда.

В Америке Голлербах прошел немало житейских испытаний (его первая работа - садовник в небольшом городке Уильтон, Коннектикут, где жила мисс Мэри Кумпф, поручительница, давшая ему кров в первые месяцы жизни в США) и «культурный шок», но всегда при этом оставался именно русским художником. «В США считают меня американским художником, родив шимся в России. В России называют русским художником, живушим в Америке. Но я считаю себя русским, который учился в Европе, но живет в Америке», - делится осознанием своей идентичности Сергей Голлербах [10].

Сергей Голлербах с 1993 г. в течение двадцати лет почти каждый год приезжает на Родину. О своих российских впечатлениях первой поездки он образно напишет в книге «Мой Дом»: «... так и тянет меня как-то «коснуться» России, подобно тому, как полуслепой человек прикосновением пальиев хочет узнать когда-то знакомое. А я ведъ не слепой. И я прикоснулся и узнал Россию. Узнал русские лииа, русскую толпу, русское небо, русский пейзаж. Узнал русские ульбки и хмурые взгллды. Я повидал родственников и друзей детства, которьх помню, когда им, как и мне, было 
16-17 лет, а сейчас под 70. Пусть не говорят мне, что русский народ сейчас не тот, ито раньше, и что страна в упадке. Не о содержании я говорю, о форме. Банкротятся идеи, рушатся империи, гибнет нравственность, но вот ресничы и брови, губы и кудри, улыбка и смех у молодых сохранилисъ, я уверен, такими же, как и 200-300 лет тому назад. А старики и старухи так же согбенны, и лича их так же испещрены русскими морщинами, как на полотнах передвижников» [5, с. 195].

Образно художник отзывается о своей непрестанной связи с Родиной и в других произведениях: «Как амулет, как талисман ношу я с собой маленький кусочек Севера, финских болот, Санкт-Петербурга» [8, с. 659].

Несмотря на то что Голллербаху не чуждо понимание неизбежных процессов глобализации, его "русскость», сохранившаяся при всех перипетиях его нелегкой судьбы, могуча и несокрушима.

Ни об одной стране мира он не говорит с такой нежностью, как о России:

«Летние ливни, / осенние стужи. / И везде лужи, / русские лужи. // В них вязли / немеикие танки, / зимою на них / скользили санки. // Лужи-часть / русской природы/ и наша участь... / Идут годы, / а они все те же, / где чаще, где реже. / Как слезы/ на щеках русской бабъ» [6, с. 61].

$\mathrm{C}$ большой теплотой и благодарностью пишет Голлербах в мемуарах о приуроченной к 50-летней годовщине Победы над нацистской Германией, прошедшей в здании Постоянного представительства России при ООН на 67-улице в Нью-Йорке большой выставке картин пяти выдающихся художников-эмигрантов второй волны, в прошлом «дипийцев-остарбайтеров» Владимира Одинокова, братьев Михаила и Виктора Лазухина, Владимира Шаталова и самого Сергея Голлербаха. По случаю открытия выставки С.В. Лавровым, постоянным представителем РФ при ООН был организован прием с участием видных деятелей широкого спектра общественных и культурных организаций русских американцев и дипломатического корпуса при ООН. В торжественной обстановке С.В. Лавров обратился с приветствием и вручил грамоты художникам - участникам этой выставки.

«Для нас это стало знаком признания нас как сынов Родины, волею судъбы выброшенных войной за пределы России», - делится Голлербах своей радостью возращения творчеством на Родину [7, с. 121], мечтая о том же и для своих собратьев. Обстоятельно описывая перипетии судьбы жизни и творчества Михаила Александровича Вербова (1896-1996), легендарного портретиста королей и президентов ${ }^{2}$, известного художника русской эмиграции, последнего ученика Ильи Репина, он выражает искреннюю надежду на то, что творчество Вербова «или хотя бы малая его часть вернется в Россию» [7, с. 161]. В 1995 г. в миссии Российской Федерации при ООН в Нью-Йорке была организована персональная выставка художника, а в октябре того же года Михаил Александрович Вербов был награжден российским орденом Дружбы народов.

...Процесс возвращения на Родину имен и творчества писателей-«ди-пийцев» начался не так давно, он продолжает набирать силу при содействии Фонда «Русский мир», Дома русского зарубежья имени А.И. Солженицына, представительства «Россотрудничества» за рубежом. В немалой степени активизации этой работы способствуют российские архивы и библиотеки,

\footnotetext{
2 Кисти Вербова принадлежат портреты нескольких королей: Густава V шведского, Альфонса XIII испанского, румынского Фердинанда I и Хуана Карлоса испанского. Он также писал портреты Индиры Ганди, Патриарха Константинопольского Афинагора I, президента Финляндии Урхо Кекконнена, Ивана Бунина, Федора Шаляпина и многих других известных деятелей культуры.
} 
образовательные учреждения, научные работники и исследователи. Так, в 2005 г. вышла книга заведующей сектором рекомендательной библиографии НИО Российской государственной библиотеки (РГБ) кандидата филологических наук М.Е. Бабичевой «Писатели второй волны русской эмиграции», в которой представлены 14 имен. Значимым изданием и для ценителей словесности, и для специалистов стал вышедший из печати в 2014 г. сборник «Восставшие из небытия. Антология писателей ди-пи и второй эмиграции», составленный доктором филологических наук В.В. Агеносовым. В подготовленном им издании представлены 44 литератора второй волны эмиграции.

Справедливо будет отметить, что некоторые известные зарубежные исследователи-подвижники давно вели кропотливую работу по вызволению имен писателей«ди-пийцев» из небытия. Среди них следует особо отметить Джона Глэда (США), Вольфганга Казака (Германия) и Рене Герра (Франция). В числе специалистов русского зарубежья, пристально занимающихся литературой второй волны эмиграции, - Марина Адамович, главный редактор «Нового журнала» (США).

В то же время большинство имен писателей второй эмиграции мало известно широкому кругу читателей. Тема писателей-«ди-пийцев» и сегодня остается невероятно острой и неоднозначной. Тем отраднее сознавать, что среди литераторов-«ди-пийцев» в лице Голлербаха мы видим самобытного летописца второй волны эмиграции.

Мемуарным книгам Сергея Голлербаха, которые читаются на одном дыхании, присуща открытая форма: читатель является соучастником творческого акта, его исподволь наделяют правом домысливать сюжет.

Говоря о мемуаристике Голлербаха, особо следует подчеркнуть, что она, как правило, щедро иллюстриро- вана рисунками автора. Однако и сами эссе могут непосредственно читаться как литературные иллюстрации к повествованию художника.

...В последние годы имя и творчество Сергея Голлербаха приобретают все большую известность. Его картины хранятся в Государственной Третьяковской галерее, Государственном Русском музее, в Российской академии художеств. Подаренные им книги и полотна неоднократно выставлялись в стенах Дома русского зарубежья. В начале ноября 2017 г. здесь прошло празднование дня рождения Сергея Голлербаха, организационно оформленное как презентация его поэтического сборника «Мысли в стихах», вышедшего накануне в Воронеже. На этом вечере особо отмечался дар Голлербаха-мемуариста в отображении характерных деталей бытия художников и литераторов поколения ди-пи, осевших после окончания Второй мировой войны в Северной Америке. А открытие Музея русского зарубежья в Москве в 2019 г. было ознаменовано экспозицией картин Сергея Львовича Голлербаха, почетного дарителя Дома русского зарубежья, передавшего 216 своих работ.

Надеемся, что празднование и осмысление грядущего 100-летнего юбилея этого непревзойденного мастера кисти и слова подарит российскому и зарубежному читателю серию глубоких исследований творчества Сергея Львовича Голлербаха, и, следовательно, летописи художественного мира русской Америки.

\section{Лumepamypa:}

1. Агеносов В.В. Восставшие из небытия. Антология Писателей ди-пи и второй эмиграции. М.: АИР0-XXI; СПб: Алетейя, 2014. 736 с.: ил.

2. Голлербах С.Л. «Вспоминая... с улыбкой»». Воспоминания / Ред. М. М. Адамович. Нью-Йорк: The New Review Publishing, 2019. 172 с.: цв. ил.

3. Голлербах С.Л. Жаркие тени города: Очерки и эссе / Предисл. Р. Герра. Париж: Альбатрос, 1990. 203 с.: ил. 
4. Голлербах С.Л. Заметки художника. Лондон: Overseas publ. interchange, 1983. 103 с.

5. Голлербах С.Л. Мой Дом: воспоминания и эссе. Париж: Альбатрос, 1994. 200 с.: ил.

6. Голлербах С.Л. Мысли в стихах. Воронеж: Центр духовного возрождения Черноземного края, 2017. 104 с.

7. Голлербах С.Л. Нью-Йоркский блокнот. Книга воспоминаний. Нью-Йорк, 2013. 252 с.: цв. ил.

8. Голлербах С.Л. Свет прямой и отраженный: Воспоминания, проза, статьи. СПб: Инапресс, 2003. 872 с.: ил.

9. Горячева Ю.Ю. Новая Россия - соотечественники Зарубежья: единое культурное пространство / Ред. Е.М. Кавелина. М.: Этносфера, 2012. 180 с.

10. Еремеева E. «Тройная» жизнь художника. Вернисаж художника Сергея Голлербаха в библиотеке-фонде «Русское зарубежье» // Иные берега. 2008. № 3(11). URL: http://www.inieberega.ru/node/63 (дата обращения: 20.06.2020)

11. Ильинский 0.П. Сергей Голлербах. Мой дом. Воспоминания и эссе. Париж, 1995 Записки русской академической группы в США = Transactions of the Association of Russian-American scholars in the USA. Русская эмиграция не в изгнании, а в послании. 1994. № 27. С. 362-363.

12. Синкевич В.А. К 90-летию Сергея Голлербаха // Связь времен. 2013. Вып. 5. С. 29-32.

\section{Yulia Goryacheva}

Literary scholar, specialist in the writing and culture of Russian emigre society in the 20th and 21st centuries. Author of numerous articles, essays and books on Russian emigre history, literary and culture and on intercultural transfers. Master's degree in Russian, Norwich University (Vermont, USA).

Member of the Moscow Union of Journalists. Member of the Editorial Boards

of the almanacs: «Literary America» and «Link of Times» (USA), tygor67@gmail.com

\section{Memoirs of Serge Hollerbach (USA): Bright portraits} of contemporaries by the outstanding artist of the second wave of emigration

Painter, essayist and writer Serge Hollerbach is the author of unique memoir essays about artistic talent of his time, the Russian emigration's «second wave», primarily DP generation. The monograph is focused on the Russian diaspora of post-WW2 New York and its bright representatives: Mikhail Verbov, Ivan Elagin, Vladimir Odinokov, Leonid Rzhevsky and other famous writers and artists.

Hollerbach's memoir essays also unveil the mystery of his development as an artist and introduces the reader to the author's understanding of art's general principles.

Keywords: Russian emigration, Russia Abroad, Serge Hollerbach, memoir essays, the second emigration wave, artist, poet

\section{АНТРОПОЛОГИЯ СОВЕТСКОСТИ}

Изучение феномена советскости и его эволюции предполагает обширную реконструкцию социокультурной среды существования советского человека, в которой в том числе складывались отличительные формы культуры повседневного общения. Коммуникативное поведение советских людей формировалось далеко не только в формате, заданном идеологическим вектором (или в противовес ему). Культурно-языковые коды узнаваемости человека советского рождались в ответ на присутствие в социокультурном пространстве неких коммуникативных «точек входа», каковыми служили в городской среде, например, телефоны-автоматы, автоматы с газированной водой или пивом, стоянки такси и др. Вокруг них спонтанно формировалась особая коммуникативная среда, которая рождала свои «логины и пароли» - словесные и материальные. И не так уж важно, последовательными или параллельными были це почки, которыми они уходили из нашей жизни, - слова, что ты не скажешь... Вместе с ними уходила эпоха, о которой весело, внимательно и с любовью рассказывает автор cmambu.

\section{Владимир Назаров}

\section{Слова, что ты не скажешь...}

Повседневная жизнь советского прошлого рождала культурные коды и поведенческие стереотипы, которые вызывают сегодня не только ностальгические воспоминания людей, рожденных в СССР, но и заслуженный интерес новых поколений, все более увлекающихся антропологией советскости.

Ключевые слова: антропология советскости, социокультурное пространство города коммуникативное поведение, коммуникативная среда, культурный код, реконструкция

\section{Назаров}

Владимир Борисович,

экономист, маркетолог,

член Совета Гильдии маркето-

логов РФ, член Союза журналистов России (Москва), vlad284@mail.ru
В современном цифровом мире старая добрая беседа становится редкостью, доступной истинным ценителями межличностного общения. Разговор онлайн главной своей задачей ставит передачу информации, он полон специфического сленга, мемов, аббревиатур. Зачастую кажется, что семидесяти- и семнадцатилетние говорят на разных 